\title{
Pengaruh Induksi Propofol dan Ketamin terhadap Kadar Procalcitonin Plasma
}

\section{The Effect of Propofol and Ketamine Induction on Plasma Procalcitonin Level}

\author{
Aunun Rofiq*, Johan Arifin*, Witjaksono* \\ *Bagian Anestesiologi dan Terapi Intensif FK Undip/ RSUP dr. Kariadi, Semarang
}

\section{ABSTRACT}

Background: Procalcitonin used as one of the inflammatory response to infection. Induction of anesthesia used drugs known to affect the increase in procalcitonin Objective: Determine the effect of differences in propofol and ketamine on levels of procalcitonin in general anesthesia

Method: a quasi experimental study on 16 subjects who performed general anesthesia. The samples were divided into 2 groups each of 8 samples, group 1 and 2 get a dose of propofol $2.5 \mathrm{mg} / \mathrm{kg}$ intravenous or ketamine $2 \mathrm{mg} / \mathrm{kg}$ intravenous as an anesthetic induction drugs. anesthesia were mainained with $\mathrm{O} 2$ and $\mathrm{N} 2 \mathrm{O}$ with a ratio of 50\%: $50 \%$. Subject blood samples were taken before induction, 4 hours and 24 hours following induction.

Results: There were significant difference in procalcitonin levels before and after treatment in the propofol group $(K 1)(p=0.008)$ and no significant difference in the ketamine group $(K 2)(p=1,00)$. Procalcitonin levels amid values $K 1$ and $K 2$ were $0.175 \pm 0.1$ and $0.05 \pm 0.05$. Propofol causes marked elevated levels of procalcitonin compared to ketamine $(p=0.053)$

Conclusion: Propofol significantly increased procalcitonin levels compared to ketamine

Keywords: propofol, ketamine, procalcitonin, general anesthesia

\section{ABSTRAK}

Latar belakang: Procalcitonin merupakan salah satu petanda respon inflamasi terhadap infeksi. Obat induksi anestesi dapat mempengaruhi kadar procalcitonin plasma.

Tujuan: Menilai pengaruh propofol dan ketamin terhadap kadar procalcitonin dalam induksi general anestesi

Metode: Studi quasi experimental terhadap 16 subjek yang menjalani general anestesi. Sampel dibagi menjadi grup 1 yang mendapatkan propofol dengan dosis $2,5 \mathrm{mg} / \mathrm{kg} b \mathrm{~b}$ intravena dan grup 2 yang mendapatkan ketamin dengan dosis $2 \mathrm{mg} / \mathrm{kg} b \mathrm{~b}$ intravena sebagai obat induksi anestesi selama prosedur penelitian, anestesi rumatan $\mathrm{O}_{2}$ dan $\mathrm{N}_{2} \mathrm{O}$ dengan rasio 50\%:50\%. Sampel darah subjek diambil sebelum induksi, jam ke-4 dan jam ke -24.

Hasil: Didapatkan perbedaaan kadar procalcitonin bermakna sebelum dan sesudah perlakuan pada kelompok propofol $(K 1)(p=0,008)$ dan perbedaan tidak bermakna pada kelompok ketamin (K2) $(p=1,00)$. Nilai tengah kadar procalcitonin K1 dan K2 


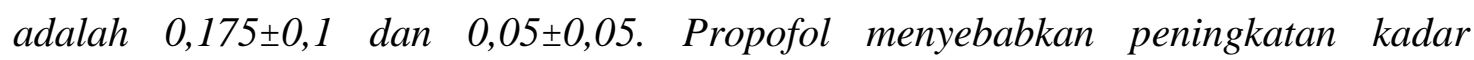
procalcitonin lebih tinggi dibandingkan ketamin $(p=0,053)$

Kesimpulan : Propofol secara bermakna meningkatkan kadar procalcitonin dibandingkan ketamin

Kata kunci : Propofol, ketamin, procalcitonin, induksi, general anestesi

\section{PENDAHULUAN}

Hampir semua tindakan operasi dilakukan dibawah pengaruh anestesi dan sebagian besar dengan anestesi umum. ${ }^{1}$ Penderita pasca operasi dengan anestesi umum mempunyai risiko terjadi Systemic Inflammatory Response Syndrome (SIRS) dan sepsis pasca operasi.

Sepsis merupakan suatu respon inflamasi sistemik terhadap infeksi, dimana patogen atau toksin dilepaskan ke dalam sirkulasi darah sehingga terjadi aktivasi proses inflamasi. ${ }^{2,3}$ Tes laboratorium yang dapat digunakan untuk mengetahui adanya proses inflamasi antara lain jumlah leukosit, laju endap darah, Creaktif protein (CRP), Tumor necrosis factor $\dot{\alpha}$ (TNF- $\dot{\alpha}$ ) dan $I L-1$ dan $I L-6 .^{3,4}$ Procalcitonin (PCT) merupakan pemeriksaan yang dapat diandalkan untuk menegakkan diagnosis infeksi bakteri akut, dan dapat pula digunakan untuk menilai proses inflamasi. Kadar PCT serum 0,5-2 ng/ml menunjukkan probabilitas infeksi bakteri pada kondisi SIRS dan berisiko terhadap terjadinya sepsis, sedangkan kadar >2ng/ml dikatakan sudah memasuki kondisi sepsis. $^{5-8}$

Tindakan anestesi untuk GA membutuhkan obat untuk induksi, antara lain propofol dan ketamin. Propofol sering digunakan karena memiliki onset cepat, durasi pendek dan waktu pulih sadar cepat 9,10 Sediaan propofol mempunyai komponen protein yang dapat memicu respon inflamasi dan merupakan media yang baik untuk pertumbuhan bakteri. ${ }^{10}$ Sedangkan Ketamin merupakan derivat phencyclidine yang dapat mensupresi produksi netrofil yang merupakan mediator inflamasi, serta meningkatkan aliran darah. Ketamin juga menurunkan migrasi lekosit ke sel endotel serta mensupresi sitokin proinflamatori dalam darah.

Penelitian yang membandingkan perubahan kadar PCT pada obat propofol dan ketamin belum pernah dilakukan namun terdapat potensi bahwa komponen utama sediaan obat mungkin mempengaruhi perubahan kadar PCT maupun menginduksi proses inflamasi. Penelitian ini bertujuan membandingkan peningkatan kadar PCT pada induksi anestesi dengan propofol dan ketamin.

\section{METODE}

Penelitian ini adalah penelitian Quasiexperimental pada 16 pasien. Dengan kriteria inklusi wanita usia 19 - 65 tahun yang menjalani operasi elektif dengan 
General Anesthesia (GA), status fisik ASA I-II. Pasien di eksklusikan bila memiliki alergi terhadap propofol dan ketamin, dan operasi bersinggungan dengan saluran pencernaan dan daerah tiroid

Pemilihan subjek penelitian dilakukan saat kunjungan prabedah di RSUP Dr Kariadi Semarang . Subjek diberikan penjelasan tentang hal-hal akan dilakukan dan diminta menandatangani lembar informed concent jika setuju mengikuti penelitian. Selanjutnya secara random sederhana pasien dibagi menjadi 2 kelompok yaitu kelompok 1(K1) Propofol dan kelompok 2 (K2) ketamin, sehingga masing-masing kelompok berjumlah 8 orang.

Semua pasien dipuasakan 6 jam sebelum operasi dan mendapatkan cairan infus ringer laktat. Setelah pasien di kamar operasi diambil sampel darah vena $10 \mathrm{cc}$ dari v. mediana cubiti kemudian segera diperiksa kadar procalcitonin pra perlakuan. Saat induksi anestesi semua pasien mendapatkan obat induksi propofol atau ketamin. Untuk pemeliharaan anestesi, obat anestesi inhalasi mengunakan enflurane dan menggunakan gas anestesi dengan perbandingan antara $\mathrm{O}_{2}: \mathrm{N}_{2} \mathrm{O}$ sebesar 50\%:50\%. Pengambilan sampel darah berikutnya dilakukan pada 4 dan 24 jam setelah induksi.

Data yang terkumpul dianalisis menggunakan piranti lunak SPSS for Windows versi 16.

\section{HASIL}

Enam belas penderita bedah yang menjalani operasi MRM pada periode Oktober 2012 hingga Desember 2012 diikutsertakan dalam penelitian ini. Karakteristik umum pasien pada masing -masing kelompok yang didapatkan dari pemeriksaan awal tersebut dideskripsikan dalam tabel 1. Sebelum dilakukan induksi, subjek menjalani pemeriksaan darah rutin dan kadar procalcitonin awal. Leukosit sebelum perlakuan berbeda bermakna diantara kedua kelompok ( $\mathrm{p}=0,015$. Kadar PCT sebelum perlakuan tidak berbeda bermakna pada kedua kelompok (tabel 2).

Pada kelompok propofol terjadi peningkatan kadar procalcitonin setelah dilakukan perlakuan sedangkan pada kelompok ketamin tidak peningkatan dari kadar procalcitonin. Kadar PCT 4 jam dan 24 jam setelah perlakuan berbeda bermakna pada kedua kelompok.(tabel 5)

\section{PEMBAHASAN}

Procalcitonin (PCT) merupakan suatu pemeriksaan laboratorium baru yang digunakan sebagai marker terjadinya SIRS dan sepsis.Kadar PCT meningkat seiring dengan peningkatan beratnya respon inflamasi. $^{11,12}$

Sediaan obat induksi anestesi yang berupa emulsi dengan komponen utama protein seperti susu kedelai dan komponen telur dapat memicu peningkatan procalcitonin oleh 
rangsangan dari luar. ${ }^{13}$ Propofol sebagai salah satu obat induksi anestesi dengan kandungan protein tinggi pada pelarutnya memiliki potensi untuk merangsang proses inflamasi hebat padat tubuh sehingga mempengaruhi mediator-mediator, sehingga menyebabkan peningkatan kadar procalcitonin. Hal ini sesuai dengan penelitian yang dilakukan V.Von Dossow dkk yang mendokumentasikan efek propofol terhadap peningkatan IL-6 dan Il-10 pada penderita dengan latar belakang konsumsi alkohol yang menjalani operasi. ${ }^{14}$ Pada penelitian ini, terbukti bahwa propofol meningkatkan kadar PCT pada penderita yang menjalani operasi MRM dengan GA ditunjukan peningkatan kadar PCT setelah 4 jam perlakuan dan 24 jam setelah perlakuan meningkat secara signifikan, dengan nilai $\mathrm{p}$,masing masing $\mathrm{p}=0,01$ pada 4 jam setelah perlakuan dan $\mathrm{p}=0,03$ pada 24 jam setelah induksi

Sedangkan ketamin mensupresi produksi netrofil yang merupakan mediator inflamasi, serta meningkatkan aliran darah. Ketamin juga menurunkan migrasi lekosit ke sel endotel serta mensupresi sitokin proinflamatori dalam darah. Ketamin mensupresi produksi LPS-induced TNF- $\alpha$, IL- 6 dan IL- 8 dan rhTNF-induced IL-6 and IL-8 dalam darah manusia. TNF- $\alpha$ adalah sitokin pertama yang timbul setelah stimulasi LPS, yang kemudian menstimulasi sekrasi IL-6 and IL-8 dari makrofag monocytes, neutrophils, dan sel endothelial. ${ }^{15}$ Ketamin pada penelitian ini tidak mempengaruhi kadar PCT setelah perlakuan hal ini sesuai dengan sediaan kedua obat berbeda dengan propofol berupa larutan dengan pelarut utama terdiri dari susu kedelai dan putih telur. ${ }^{1,8,10}$

Susanne dkk mendokumentasikan bahwa sevoflurane lebih menekan pelepasan PCT dibandingkan dengan propofol dan menyimpulkan bahwa sevofluran lebih menekan respon inflamasi dibandingkan propofol. ${ }^{13}$ Sejalan dengan penelitian tersebut, dalam penelitian ini juga dapat dilihat peningkatan kadar leukosit pada kelompok propofol lebih tinggi dibandingkan kelompok ketamin ditunjukan dengan nilai peningkatan leukosit. Pada penelitian ini pada peningkatan kadar leukosit kelompok propofol lebih signifikan pada 4 jam $(\mathrm{p}=0,002)$ dan 24 jam $(\mathrm{p}=0,004)$ setelah perlakuan.

Kadar PCT meningkat secara signifikan pada kelompok propofol dibandingkan dengan ketamin setelah 24 jam $(\mathrm{p}=0,008)$.

Penelitian ini menunjukan bahwa propofol dapat menyebabkan peningkatan kadar PCT pada penderita dengan induksi anestesi sehingga berpotensi untuk terjadinya SIRS hingga sepsis

\section{SIMPULAN}

Pada penelitian ini, didapatkan kesimpulan bahwa induksi anestesi dengan Propofol 2,5 mg/kgbb untuk 
Tabel 1 Karakteristik umum subyek pada masing-masing kelompok

\begin{tabular}{|c|c|c|c|c|}
\hline No & & $\begin{array}{c}\text { Propofol } \\
(\mathrm{n}=8) \\
\text { Median(min-max }) \\
\end{array}$ & $\begin{array}{c}\text { Ketamin } \\
(\mathrm{n}=8) \\
\text { Median(min-max }) \\
\end{array}$ & $\mathbf{p}$ \\
\hline 1 & $\begin{array}{c}\text { Umur } \\
\text { (tahun) }\end{array}$ & $40,5(21-61)$ & $38,5(23-65)$ & $\mathbf{0 , 7 2 5}$ \\
\hline 2 & $\begin{array}{c}\text { Lama operasi } \\
\text { (menit) }\end{array}$ & $135,0(120-150)$ & $120,0(75-160)$ & $\mathbf{0 , 3 8 3}$ \\
\hline 3 & $\begin{array}{c}\text { Hb } \\
\text { Sebelum perlakuan (gr/dl) } \\
\end{array}$ & $12,9(10,3-14,9)$ & $11,9(10,2-14,0)$ & 0,195 \\
\hline 4 & $\begin{array}{c}\text { Leukosit } \\
\text { sebelum perlakuan }\left(\mathrm{mm}^{3}\right) \\
\end{array}$ & $6050(4500-8600)$ & $6300(4600-8700)$ & $\mathbf{0 , 0 1 5}$ \\
\hline 5 & $\begin{array}{c}\text { Procalcitonin } \\
\text { Sebelum perlakuan } \\
(\mathrm{ng} / \mathrm{dl})\end{array}$ & $0,05(0,05-0,05)$ & $0,05(0,05-0,05)$ & 1,00 \\
\hline
\end{tabular}

Tabel 2 Perbedaan kadar PCT (ng/dl) sebelum induksi antara kedua kelompok

\begin{tabular}{llcl}
\hline No & Deskripsi & Median $($ min-max $)$ & P \\
\hline $\mathbf{1}$ & Propofol & $0,05(0,05-0,05)$ & 1,00 \\
\hline $\mathbf{2}$ & Ketamin & $0,05(0,05-0,05)$ & 1,00 \\
\hline
\end{tabular}

Tabel 3. Perbedaan kadar PCT (ng/dl) 4 jam setelah induksi antara kedua kelompok.

\begin{tabular}{cccc}
\hline No & Deskripsi & Median (min-max) & P \\
\hline $\mathbf{1}$ & Propofol & $0,06(0,05-0,08)$ & 0,010 \\
$\mathbf{2}$ & Ketamin & $0,05(0,05-0,05$ & 1,00 \\
\hline
\end{tabular}

Tabel 4. Perbedaan kadar PCT (ng/dl) 24 jam setelah induksi antara kedua kelompok.

\begin{tabular}{cccc}
\hline No & Deskripsi & Median (min-max) & P \\
\hline $\mathbf{1}$ & Propofol & $0,10(0,05-0,08)$ & 0,03 \\
\hline $\mathbf{2}$ & Ketamin & $0,05(0,05-0,05$ & 1,00 \\
\hline
\end{tabular}

Tabel 5. Perbedaan kadar PCT (ng/dl) antara sebelum induksi, 4jam dan 24 jam setelah induksi.

\begin{tabular}{|c|c|c|c|c|c|c|c|c|}
\hline \multirow{2}{*}{ No } & \multirow{2}{*}{ Deskripsi } & \multirow{2}{*}{$\begin{array}{l}\text { Sebelum } \\
\text { Induksi }\end{array}$} & \multicolumn{2}{|r|}{$4 \mathrm{Jam}$} & \multicolumn{2}{|r|}{$24 \mathrm{jam}$} & \multicolumn{2}{|r|}{$\begin{array}{c}\text { Antara } 4 \text { jam } \\
\text { dan } 24 \text { jam }\end{array}$} \\
\hline & & & $\mathrm{P}$ & $\begin{array}{l}\text { Median } \\
(\min -\max )\end{array}$ & $\mathrm{P}$ & $\begin{array}{l}\text { Median } \\
(\min -\max )\end{array}$ & $\mathrm{P}$ & $\mathrm{P}$ \\
\hline 1 & Propofol & $\begin{array}{l}0,05 \\
(0,05-0,05)\end{array}$ & 1 & $\begin{array}{r}0,06 \\
(0,05-0,08)\end{array}$ & 0,01 & $\begin{array}{c}0,10 \\
(0,05-0,08)\end{array}$ & 0,03 & 0,008 \\
\hline 2 & Ketamin & $\begin{array}{l}0,05 \\
(0,05-0,05)\end{array}$ & 1 & $\begin{array}{c}0,05 \\
(0,05-0,05\end{array}$ & 1 & $\begin{array}{c}0,05 \\
(0,05-0,05)\end{array}$ & 1 & 1 \\
\hline
\end{tabular}


lebih meningkatkan kadar procalcitonin setelah 4 jam dan 24 jam perlakuan dibandingkan Ketamin 2 mg/kgbb.

\section{DAFTAR PUSTAKA}

1. Danish MA. Dr Azam's Notes in Anesthesiology. Bangalore: Anesthesiology \& Critical Care Department B.M.Jain Hospital;2010. available from: http:// www.drazam.com/index.php?

$\mathrm{p}=1$ 8_Education-Teaching-Programme (accessed 18 Jun 2012)

2. Balk RA. Severe Sepsis and Septic Shock, Definition, Epidemiology and Clinical Manifestation. Crit Care Clin 2000;16 (2) 179-92.

3. Delinger RP. Surviving Sepsis Compaign Guidelines for Management of Severe Sepsis and septic Shock. Crit Care Med 2004; 32: 858-873

4. Pohan HT. Pemeriksaan Procalcitonin untuk Diagnosis Infeksi Berat. In: Pohan HT, Widodo D, editor. Penyakit Infeksi. Jakarta: FKUI; 2004. P. 32-9

5. Reinhart K, Karzai W. Procalcitonin as a marker of the systemic inflammatory response to infection. Intensive Care Med. 2000 Sep;26(9):1193-200

6. Meisner $M$, Brunkhorst FM, Reith $\mathrm{H}$, Schmidt J. Clinical Experiences with a New Semi-Quantitative Solid Phase Immunoassay for Rapid Measurement of Procalcitonin. Clin Chem Lab Med 2000; 38 (10): 989-95

7. Simon L, Gauvin F, Amre DK, et al. Serum Procalcitonin and C-Reaktive Protein Levels as Marker of Bacterial Infection : A
Systematic Review and Meta-analysis. Clinical Infectious Diseases 2004; 39: 206 17

8. O'Connor E, Venkatesh B, lipman J, et al. Procalcitonin in Critical Illness. Critical Care and Resuscitation 2001; 3: 236-243

9. Trapani G, Altomare C, Liso G, Sanna E, Biggio G. Propofol in anesthesia. Mechanism of action, structure-activity relationships and drug delivery. Curr Med Chem. 2000 Feb;7(2):249-71

10. Stoelting RK, Hillier SC, Pharmacology \& Physiology in Anesthetic Practice, 4th edition, Philadelphia : Lippincott; 2006.

11. Ismanoe G. The Role of Cytokine in The Pathobiology of Sepsis : proceeding of the 2nd Indonesian Sepsis Forum. March 7th9th, 2008, Surakarta : UNS Press; 2008

12. Susanne C, Peter F, Joerg M, Klaus P. Effect of sevoflurane and propofol on procalcitonin and C-reactive protein concentration in patients undergoing offpum coronary artery bypass graft surgery. Anesthesiology 2002; 96: A155.

13. Bozeman WP, Kleiner DM, Huggett V. A comparison of rapid-sequence intubation and etomidate-only intubation in the prehospital air medical setting. Prehosp Emerg Care. 2006; 10(1): 8-13.

14. Dosow V.V, Haas A, Kastrup M, Geyer T, Spies D. Influence of remifentanil versus fentanyl analgesia on the perioperative course of plasma procalcitonin levels in patients undergoing cardiac surgery. Anesthesiology 2005; 103: A320.

15. Aalto H, Takala A, Kautiainen $H$. Laboratory markers of systemic inflammationas predictors of bloodstream infection inacutely ill patients admitted to hospital in medical emergency. Eur J Clin Microbiol Infect Dis 2004; 23:699-704 